\title{
Trifuntional Oligoetherols and Polyurethane Foams with Carbazole Ring
}

\author{
Renata Lubczak \\ Faculty of Chemistry, Rzeszów University of Technology, Rzeszów, Poland \\ Email: rlubczak@prz.edu.pl
}

Received November 19, 2011; revised December 20, 2011; accepted January 5, 2012

\begin{abstract}
The method of synthesis of trifuntional oligoetherols with carbazole ring from 9-(2,3-epoxypropyl)carbazole and diethanolamine and oxiranes like ethylene and propylene oxide was presented. Structure and some physicochemical properties of the products were described. The oligoetherols were demonstrated as good substrates for synthesis of polyurethane foams of enhanced thermal resistance. It has been found that the obtained foams are rigid at room temperature and their apparent density was $34 \mathrm{~kg} / \mathrm{m}^{3}-44 \mathrm{~kg} / \mathrm{m}^{3}$. The water uptake was low, maximum to $10.5 \mathrm{mass} \%$. Dynamic thermal analysis of this foams showed that $5 \%$ mass loss starts at $200^{\circ} \mathrm{C}-220^{\circ} \mathrm{C}$, while temperature of $50 \%$ mass loss was $340^{\circ} \mathrm{C}-370^{\circ} \mathrm{C}$. Concomitantly the increase of compression strength was observed.
\end{abstract}

Keywords: Oligomers; Ring-Opening Polymerization; Polyurethanes; Thermal Properties

\section{Introduction}

Polymers containing carbazole ring have the critical importance for physical parameters of polymers, like: phase transition temperatures, solubility in polymer in organic solvents, electric conductivity, and ability to form chargetransfer complexes [1-7]. Carbazole decomposes at temperatures higher than $260^{\circ} \mathrm{C}$. High thermal stability of carbazole prompted us to introduce carbazole into polyetherols in order to obtain products of high thermal stability, i.e. polyetherols themselves and polymeric products obtainable from them; polyurethanes and polyesters. Carbazole is mono-functional compound and this is the reason of limited application for synthesis of oligoetherols by its reaction with oxiranes. Therefore, previous studies were devoted to increase its functionality and solubility of carbazole derivatives in oxiranes [8]. The di-functional oligo and polyetherols with carbazole ring were not known till now except for some preliminary results from this lab [9-11]. Here we have presented the method of synthesis of tri-functional oligoetherols with carbazole ring inside chain and apply them to obtain polyurethane foams with enhanced thermal resistance.

\section{Experimental}

\subsection{Syntheses}

The synthesis of 9-(2,3-epoxypropyl)carbazole (EPC) was performed as previously [8].

\subsection{Opening of Epoxide Ring with Diethanolamine}

To a $100 \mathrm{~cm}^{3}$ three-necked roun bottom flask equipped with reflux condenser, mechanical stirrer and thermometer $18.0 \mathrm{~g}$ ( 0.11 mole) of EPC and $15.6 \mathrm{~cm}^{3}$ (0.16 mole) of diethanolamine (DEA, pure, Fluka, Buchs, Switzerland) were introduced. The mixture was stirred and heated until dissolving of substrates (at temperature ca. $60^{\circ} \mathrm{C}$ ), then $0.1 \mathrm{~cm}^{3}$ triethylamine (TEA, pure, Fluka, Buchs, Switzerland) catalyst was added. The mixture was heated to $120^{\circ} \mathrm{C}$. The progress of reaction was monitored by determination of epoxide number (EN). Then, $50 \mathrm{~cm}^{3}$ distilled water was added, the mixture was vigorously stirred and heated at $90^{\circ} \mathrm{C}$ for about one hour to rinse the diethanolamine off. The mixture was cooled down to room temperature and water layer was removed, washed couple of times with water and final product:

9-(9-carbazolyl)-3-aza-6-oxanonane-1,6-diol (CAOD, I) as dense brown resin was vacuum dried at $80^{\circ} \mathrm{C}$ to remove water.

Analytical of CAOD

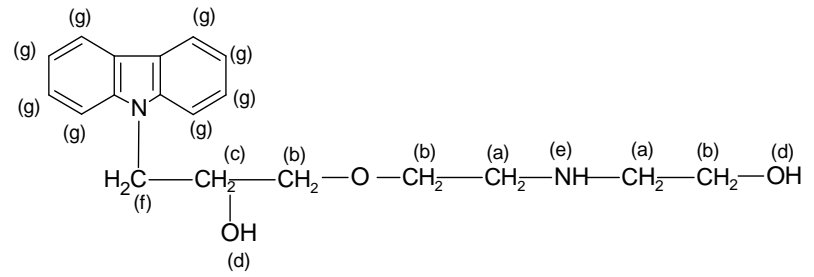

(I) 
Analytical of products: Yield: 61.5\%; elemental analysis-\% Calcd. C 69.49, N 8.53, H 7.37, \% Found C 69.63, N 8.31, H 7.54; IR (ATR) [ $\mathrm{cm}^{-1}$ ]: 3300 (NH, OH), 3049 (Ar-H), 2818 - $2927\left(\mathrm{CH}_{2}, \mathrm{CH}\right), 1652(\mathrm{NH}), 1626$ (C=C in carbazole ring), $1451\left(\mathrm{CH}_{2}\right), 1324(\mathrm{C}-\mathrm{N}), 1210,1152$ (C-O), 1034 - 1066 (C-O-C), 747, 720 (Ar-H); ${ }^{1} \mathrm{H}-\mathrm{NMR}$ (DMSO-d ${ }_{6}$ [ppm]: a $2.5-2.7$, b 3.2 - 3.5, c 4.65, d + e 3.9 - 4.1, f 4.4 - 4.6, g 7.0 - 8.1.

\subsection{Reaction of CAOD with Oxiranes}

In a pressure reactor of $250 \mathrm{~cm}^{3}$ volume equipped with magnetic stirrer and thermometer $25.0 \mathrm{~g}$ (0.076 mol) of CAOD, $1 \mathrm{~cm}^{3}$ (0.007 mole) catalyst (TEA) and $20.1 \mathrm{~g}(0.46$ mola) of ethylene oxide (EO, pure, Fluka, Buchs, Switzerland) or $26.5 \mathrm{~g}(0.46 \mathrm{~mol})$ of propylene oxide (PO, pure, Fluka, Buchs, Switzerland) were placed. The mixture was stirred and heated to $75^{\circ} \mathrm{C}$. The progress of reaction was monitored by determination of EN. The products were brown resins, from which the catalyst was removed by distillation under reduced pressure $(p=2132 \mathrm{~Pa}$, temp. $80^{\circ} \mathrm{C}$ ).

Analytical of oligoetherols (III, formula in Results and Discussion) obtained from CAOD and oxiranes:

$\mathrm{R}=-\mathrm{H}$; IR (ATR) $\left[\mathrm{cm}^{-1}\right]: 3409(\mathrm{OH}), 3046$ (Ar-H), 2866 - $2919\left(\mathrm{CH}_{2}, \mathrm{CH}\right), 1626,1596(\mathrm{C}=\mathrm{C}), 1484,1452$ $\left(\mathrm{CH}_{2}\right), 1326(\mathrm{C}-\mathrm{N}), 1214$ (C-O in alcohols ), 1061 - 1098 (C-O-C), 751, 721 (Ar-H) (Figure 1); ${ }^{1} \mathrm{H}-\mathrm{NMR}$ (DMSO$\left.\mathrm{d}_{6}\right)$ [ppm]: $7.0-8.1(\mathrm{Ar}-\mathrm{H}), 4.4-4.6\left(>\mathrm{N}-\mathrm{CH}_{2}-\right), 3.95$ (-CH-OH), 3.4 - 3.5 (- $\left.\mathrm{CH}_{2}-\mathrm{O}-\right), 2.6$ - $2.8\left(-\mathrm{CH}_{2}-\mathrm{N}-\mathrm{CH}_{2}-\right.$ $\left.\mathrm{CH}_{2}-\mathrm{O}-\right)$ (Figure 2).

$\mathrm{R}=-\mathrm{CH}_{3}$; IR (ATR) $\left[\mathrm{cm}^{-1}\right]: 3414(\mathrm{OH}), 3051(\mathrm{Ar}-\mathrm{H})$, 2868 - $2968\left(\mathrm{CH}_{3}, \mathrm{CH}_{2}, \mathrm{CH}\right), 1627,1597$ (C=C), 1484, $1453\left(\mathrm{CH}_{2}\right), 1372\left(\mathrm{CH}_{3}\right), 1325(\mathrm{C}-\mathrm{N}), 1215,1152$ (C-O in alcohols), 1087 (C-O-C), 759, 724 (Ar-H); ${ }^{1} \mathrm{H}-\mathrm{NMR}$ (DMSO-d ${ }_{6}$ [ppm]: 7.0 - $8.1(\mathrm{Ar}-\mathrm{H}), 4.4$ - $4.6\left(>\mathrm{N}-\mathrm{CH}_{2}\right.$; $-\mathrm{OH}), 3.7$ - $3.9(\mathrm{CH}), 3.2$ - $3.7\left(\mathrm{CH}_{2} \mathrm{O}-,>\mathrm{CHO}-\right), 2.7$ $\left(-\mathrm{CH}_{2}-\mathrm{N}-\mathrm{CH}_{2}-\mathrm{CH}_{2}-\mathrm{O}-\right)$, $0.7-1.1\left(-\mathrm{CH}_{3}\right)$.

\subsection{Analytical Methods}

The progress of reaction of carbazole with epichlorohydrin and oxiranes was monitored by EN, which was determined by hydrochloric acid method in dioxane [12]. Elemental analysis for C, H, N, were done with EA 1108, Carlo-Erba analyzer. The ${ }^{1} \mathrm{H}-\mathrm{NMR}$ spectra of products were recorded at $500 \mathrm{MHz}$ Bruker UltraShield in DMSO- $\mathrm{d}_{6}$ with hexamethyldisiloxane as internal standard. IR spe-ctra were registered on PARAGON 1000 FT IR Perkin Elmer spectrometer in $\mathrm{KBr}$ pellets or ATR technique. The number-average molecular mass $M_{n}$ of obtained oligoetherols was determined cryoscopically in DMSO solvent. Thermal analyses of oligoetherols and foams (DTA, DTG and TG) were performed in ceramic crucible at $20^{\circ} \mathrm{C}-600^{\circ} \mathrm{C}$ temperature range, about $200 \mathrm{mg}$ sample, under air atmo- sphere with Termowaga TGA/DSC 1 derivatograph, Mettler.

\subsection{Physical Properties of Oligoetherols}

Refraction index, density, viscosity, and surface tension of oligoetherols were determined with Abbe refractometer, picnometer, Höppler viscometer (typ BHZ, prod. Prüfgeratewerk, Germany) and by the detaching ring method, respectively.

\subsection{Foam Preparation}

Foaming tests were conducted on laboratory scale in 250 $\mathrm{cm}^{3}$ paper cups at room temperature. In details oligoetherol (10 g) was mixed with $0.2 \mathrm{~g}$ of Silicone 5340 (pure, Houdry Hülls, USA) as surfactant, TEA as catalyst (1.25 $3.76 \mathrm{wt} \%)$ and water (2\% wt\%) with respect to oligoetherols. A calculated portion of diphenylmethane 4,4'-diisocyanate (commercial isocyanate containing three-functional isocyanates at the level of 30\%; MDI, pure, Merck, Darmstadt, Germany, was used) was then added and the mixture was vigorously stirred until the contents were creamed. Test samples were cut out from the foams thus obtained.

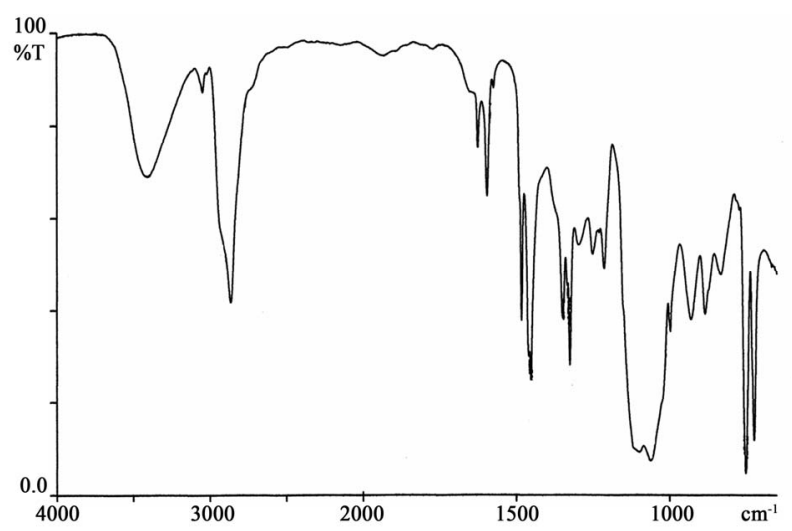

Figure 1. IR spectrum of oligoetherols obtained in reaction of CAOD with EO.

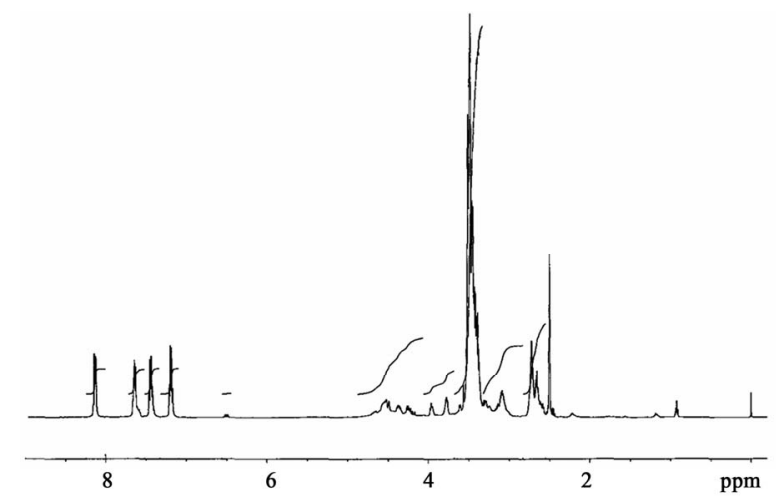

Figure 2. H-NMR spectrum of oligoetherols obtained in reaction of CAOD with EO. 


\subsection{Studies of Foams}

The following properties of foams were studied: apparent density [13], water uptake [14], linear shrinkage estimated on the basis of the change of linear dimension of the sample heated for 4 hours at $100^{\circ} \mathrm{C}$ [15], thermal stability as the weight loss at $150^{\circ} \mathrm{C}$ within one month and compression strength [16].

\section{Results and Discussion}

The reaction of carbazole with epichlorohydrin led to the formation of EPC (II), which underwent ring opening upon reaction with diethanolamine in presence of TEA to give three-functional semiproduct (I) according to the following reaction scheme:

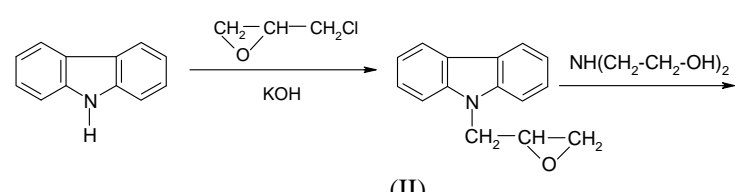

(II)

The process was performed without any solvent, using two equivalents of diethanolamine. The obtained product was semisolid resin, which was identified by elemental analytical, IR and ${ }^{1} \mathrm{H}$ NMR spectra (see Experimental; Analytical of CAOD). In the ${ }^{1} \mathrm{H}$ NMR spectrum the multiplet at 7.0 - 8.1 ppm from carbazole ring protons was observed. The resonances of -OH and $\mathrm{NH}$ were present together with 3.9 - 4.1 ppm region, the signals of methylene protons of $-\mathrm{CH}_{2} \mathrm{O}$ - were found at 3.2 - $3.5 \mathrm{ppm}$, while methine proton resonances were observed at $4.65 \mathrm{ppm}$. The aromatic C-H bands were observed at 747 and 720 $\mathrm{cm}^{-1}$ in the IR spectra, the stretching $\mathrm{OH}$ and $\mathrm{NH}$ bands were found at and $1152 \mathrm{~cm}^{-1}$ and $1652 \mathrm{~cm}^{-1}$ respectively, while valence bands of C-O-C were found at 1034 - 1066 $\mathrm{cm}^{-1}$. The obtained product is readily soluble in oxiranes: $\mathrm{EO}$ and $\mathrm{PO}$ at room temperature. Addition of TEA to such a solution and heating the mixture to $60^{\circ} \mathrm{C}$ triggered the reaction of formation of three-functional oligoetherols III according to the scheme:
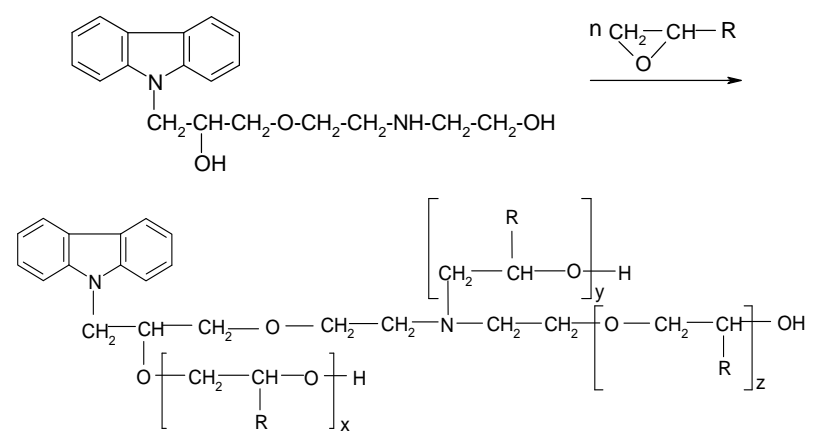

(III)

Elemental analysis and $M_{n}$ confirm the structure of the oligoetherols (III, $x+y+z=6$, Table 1). IR spectra of oligoetherols (Figure 1) are remarkably different from that of semiproduct. The intensity of the band at $1098 \mathrm{~cm}^{-1}$ increased indicating formation of ether bonds. Also the band at $2900 \mathrm{~cm}^{-1}$ grew, indicating the incorporation of oxyalkylene units into oligoetherol. The intensity of the resonance at $3.5 \mathrm{ppm}$ in the ${ }^{1} \mathrm{H}-\mathrm{NMR}$ of oligoetherols (Figure 2) increased according to the increase of number of oxyalkylene units in a product. Simultaneously the resonances at 4.2 - $4.6 \mathrm{ppm}$ diminished illustrating the disappearance of hydroxyl protons due to progressing reaction of $\mathrm{OH}$ with oxirane.

The oligoetherols were obtained from the CAOD: oxirane 1:6 molar ratio system. Some physical parameters like refraction index, density, viscosity and surface tension in function of temperature were studied (Figures 3-6). Typical changes of those parameters in function of temperature were observed. The products obtained from EO had higher refraction index and density than those synthesized from PO. Generally the physical properties of oligoetherols synthesized here are similar to those of typical polyols used for obtaining polyurethane foams [17], with

Table 1. Table type styles (Table caption is indispensable).
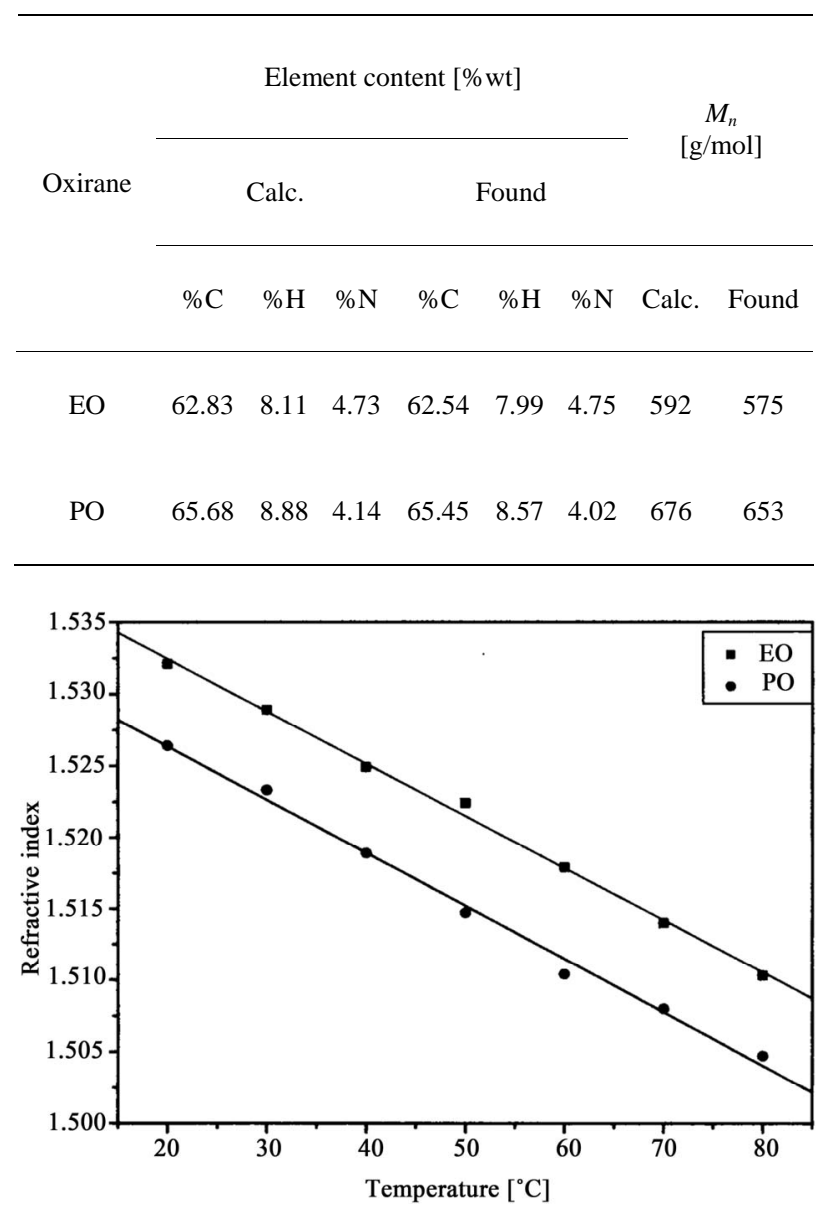

Figure 3. Refractive index of oligoetherols obtained in reaction of CAOD with oxiranes versus temperature. 


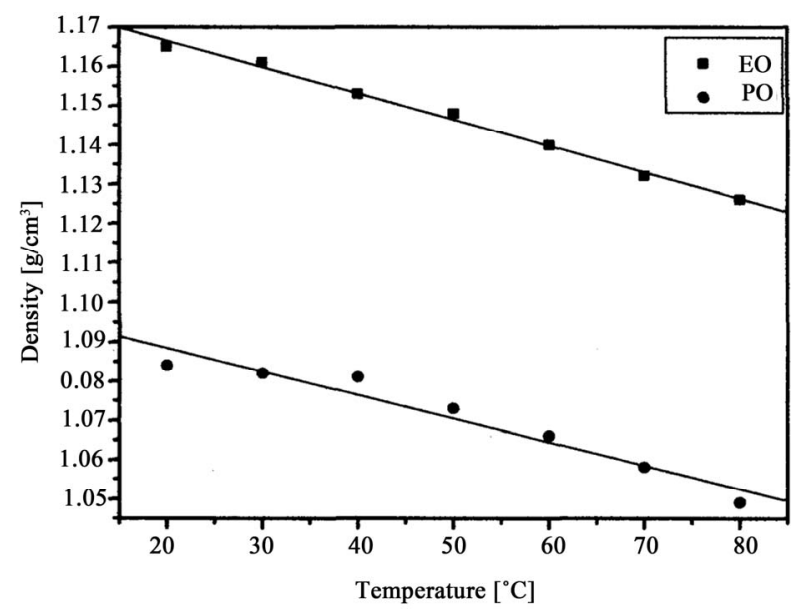

Figure 4. Density of oligoetherols obtained in reaction of CAOD with oxiranes versus temperature.

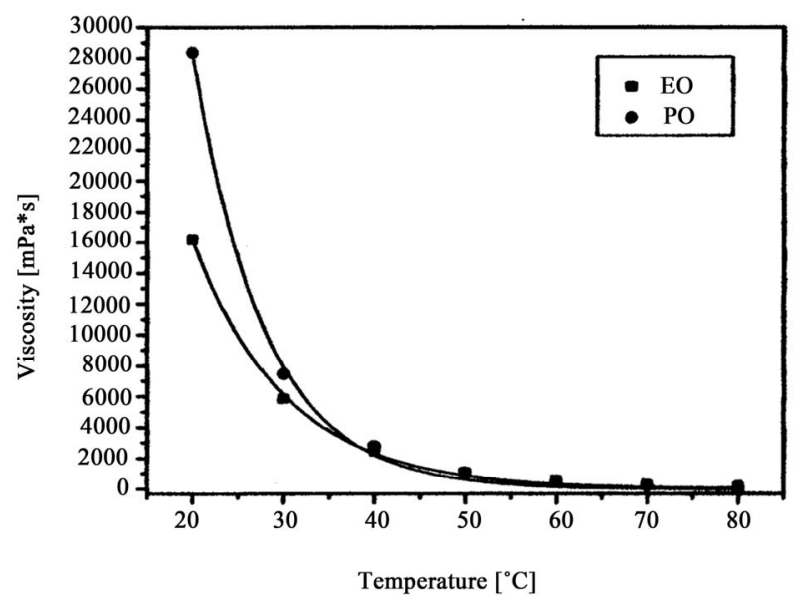

Figure 5. Viscosity of oligoetherols obtained in reaction of CAOD with oxiranes versus temperature.

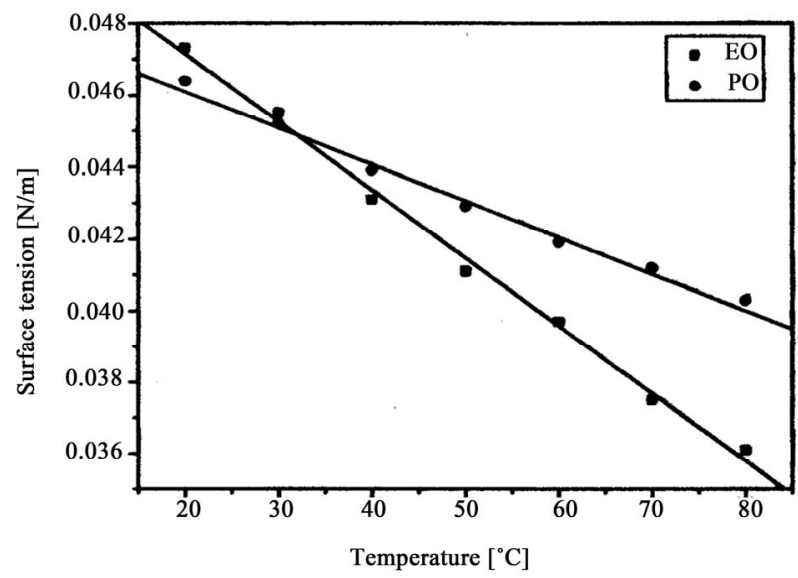

Figure 6. Surface tension of oligoetherols obtained in reaction of CAOD with oxiranes versus temperature.

the exception of viscosity, whichever is higher. The synthesized oligoetherols have good thermal resistance (Table 2). Their thermal decomposition starts at $230^{\circ} \mathrm{C}$ - $240^{\circ} \mathrm{C}$ (mass loss $5 \%$ ), while their temperature of $50 \%$ decomposition falls into $460^{\circ} \mathrm{C}-480^{\circ} \mathrm{C}$ region. High thermal resistance of these products suggested their usefulness as substrates for thermally resistant polyurethane foams.

The polyurethane foams were performed on laboratory scale (Table 3). The optimization of amount of isocyanate, foaming agent (amount of water), catalyst and kind of oligoetherol was performed for foaming. The water amount was optimized as $2 \%$ water related to mass of oligoetherol; the use of higher water percentage led to the formation of irregular pores. The amount of catalyst was also crucial; the rigid foams were obtained when $1.25 \%$ catalyst was applied in case of oligoetherol obtained from EO was used and 3.76\% in case of oligoetherol obtained from PO.

The best foams were obtained when the molar ratio of 4,4'-diphenylmethane diisocyanate to number of hydroxyl groups was maintained at the level of 1.80 for the oligoetherol obtained from EO and 1.44 in case of the oligoetherol synthesized from PO. Lower or higher ratio led to underhardened foams with large pores.

Foaming compositions showed short creaming times (to $15 \mathrm{sec}$ ) and expanding times (to $44 \mathrm{sec}$ ). Drying times in case of compositions from EO was 1 seconds, while in case of PO it was as long as 60 seconds.

The best foams, the rigid ones and with unisized pores were subjected to density, size stability at $150^{\circ} \mathrm{C}$, water uptake, thermal resistance and change of mechanical properties upon thermal exposure (Table 4). It has been found that the obtained foams are rigid at room temperature and their apparent density was $34 \mathrm{~kg} / \mathrm{m}^{3}-44 \mathrm{~kg} / \mathrm{m}^{3}$. The water uptake was low, maximum to 10.5 mass $\%$. The dimensional stability at $150^{\circ} \mathrm{C}$ measurements revelaed that the dimension change it was no larger than $8.0 \%$ of initial dimension.

Dynamic thermal analysis showed that $5 \%$ mass loss starts at $200^{\circ} \mathrm{C}-220^{\circ} \mathrm{C}$, while temperature of $50 \%$ mass loss was $340^{\circ} \mathrm{C}-370^{\circ} \mathrm{C}$ (Table 2). Long-lasting, static measurements of thermal resistance were conducted at $150^{\circ} \mathrm{C}$ for one month (Figure 7). Continuous decrease of foam

Table 2. Thermal stability of oligoetherols and polyurethane foams.

\begin{tabular}{ccccc}
\hline Product & $\begin{array}{c}\mathrm{T}_{5 \%} \\
{\left[{ }^{\circ} \mathrm{C}\right]}\end{array}$ & $\begin{array}{l}\mathrm{T}_{10 \%} \\
{\left[{ }^{\circ} \mathrm{C}\right]}\end{array}$ & $\begin{array}{l}\mathrm{T}_{25 \%} \\
{\left[{ }^{\circ} \mathrm{C}\right]}\end{array}$ & $\begin{array}{c}\mathrm{T}_{50 \%} \\
{\left[{ }^{\circ} \mathrm{C}\right]}\end{array}$ \\
\hline $\begin{array}{c}\text { Oligoetherol } \\
\text { CAOD + EO }\end{array}$ & 230 & 260 & 320 & 480 \\
$\begin{array}{c}\text { Foam obtained from oligoetherol } \\
\text { CAOD + EO }\end{array}$ & 220 & 260 & 320 & 370 \\
$\begin{array}{c}\text { Oligoetherol } \\
\text { CAOD + PO }\end{array}$ & 240 & 260 & 300 & 460 \\
$\begin{array}{c}\text { Foam obtained from oligoetherol } \\
\text { CAOD + PO }\end{array}$ & 200 & 220 & 290 & 340 \\
\hline
\end{tabular}


Table 3. The influence of composition of foaming process.

\begin{tabular}{|c|c|c|c|c|c|c|c|c|}
\hline \multirow{2}{*}{$\begin{array}{l}\text { Oligoetherol } \\
\text { obtained with } \\
\text { the use of }\end{array}$} & \multirow{2}{*}{$\begin{array}{l}\text { Composition } \\
\text { number }\end{array}$} & \multicolumn{2}{|c|}{$\begin{array}{l}\text { Composition* g/100 g } \\
\text { of oligoetherol }\end{array}$} & \multirow{2}{*}{$\begin{array}{c}\text { Molar } \\
\text { ration } \\
\text { OH:NCO } \\
\text { (isocyanate } \\
\text { coefficient }\end{array}$} & \multicolumn{3}{|c|}{ Foaming process } & \multirow{2}{*}{$\begin{array}{l}\text { Characteristics of } \\
\text { foams just prepared }\end{array}$} \\
\hline & & Izocyanate & TEA & & $\begin{array}{c}\text { Time of } \\
\text { creaming } \\
{[\mathrm{s}]}\end{array}$ & $\begin{array}{l}\text { Time of } \\
\text { expanding } \\
{[\mathrm{s}]}\end{array}$ & $\begin{array}{l}\text { Time of } \\
\text { drying } \\
{[\mathrm{s}]}\end{array}$ & \\
\hline \multirow{5}{*}{ EO } & 1 & 116 & 1.25 & 1.80 & 10 & 13 & 2 & rigid \\
\hline & 2 & 118 & 1.25 & 1.64 & 8 & 12 & 2 & large pores, underhardened \\
\hline & & & & & & & & \\
\hline & 3 & 116 & 1.25 & 1.80 & 10 & 21 & 1 & rigid, regular pores \\
\hline & 5 & 124 & 1.25 & 1.74 & 10 & 22 & 1 & rigid, regular pores \\
\hline \multirow{3}{*}{$\mathrm{PO}$} & 6 & 95 & 3.76 & 1.28 & 15 & 44 & 120 & underhardened \\
\hline & 7 & 104 & 3.76 & 1.44 & 7 & 35 & 60 & rigid, regular pores \\
\hline & 8 & 114 & 3.76 & 1.58 & 12 & 42 & 90 & underhardened \\
\hline
\end{tabular}

*Amount of surfactant and water $2 \mathrm{~g}$ per $100 \mathrm{~g}$ of oligoetherols.

Table 4. Some properties of polyurethane foams.

\begin{tabular}{|c|c|c|c|c|c|c|c|c|c|}
\hline \multirow{2}{*}{$\begin{array}{l}\text { Oligoetherol obtained } \\
\text { with the use of }\end{array}$} & \multirow{2}{*}{$\begin{array}{l}\text { Density } \\
{\left[\mathrm{kg} / \mathrm{m}^{3}\right]}\end{array}$} & \multicolumn{3}{|c|}{$\begin{array}{c}\text { Water uptake } \\
\text { [\%] after }\end{array}$} & \multicolumn{3}{|c|}{$\begin{array}{c}\text { Linear dimension stability [\%] } \\
\text { at temperature } 150^{\circ} \mathrm{C} \\
\text { after } 40 \mathrm{~h}\end{array}$} & \multicolumn{2}{|c|}{$\begin{array}{l}\text { Compression Strength } \\
{[\mathrm{MPa}]}\end{array}$} \\
\hline & & 5 min. & $3 \mathrm{~h}$ & $24 \mathrm{~h}$ & $\begin{array}{l}\text { Length } \\
\text { change }\end{array}$ & $\begin{array}{l}\text { Width } \\
\text { change }\end{array}$ & $\begin{array}{l}\text { Depth } \\
\text { change }\end{array}$ & $\begin{array}{c}\text { Before } \\
\text { exposition }\end{array}$ & $\begin{array}{c}\text { After } \\
\text { exposition }\end{array}$ \\
\hline EO & 33.7 & 6.29 & 7.65 & 10.54 & 4.05 & 8.04 & 2.55 & 0.151 & 0.336 \\
\hline PO & 43.6 & 4.35 & 5.08 & 8.77 & 0.75 & 3.17 & 0.00 & 0.217 & 0.367 \\
\hline
\end{tabular}

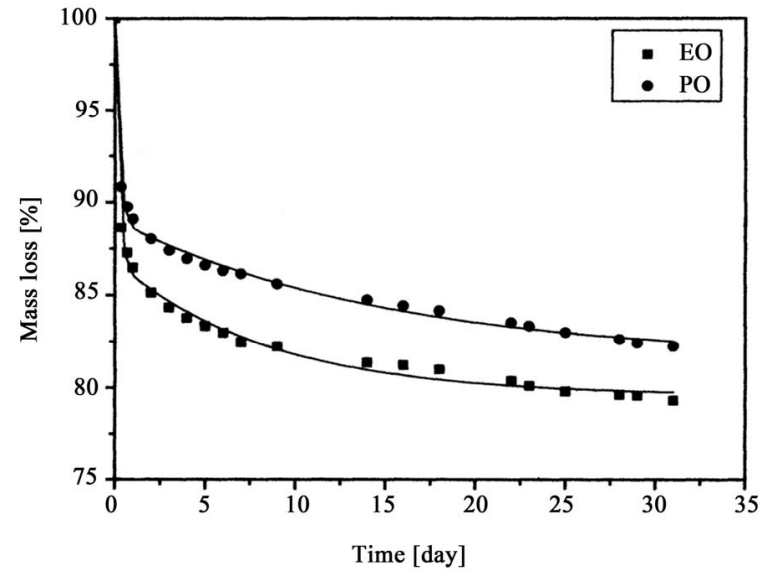

Figure 7. Thermal stability of polyurethane foams as the weight loss after heating at $150^{\circ} \mathrm{C}$ for a month.

mass was observed throughout the test, however the largest mass loss was noticed at the first day of heating. The mass loss of foam obtained from oligoetherol synthesized from CAOD and PO or EO it was 15 - 20 mass\% within one month. Concomitantly the increase of compression strength was observed (Table 4), for instance the foams obtained from oligoetherol synthesized with EO showed twice increase of compression strength after one month heating at $150^{\circ} \mathrm{C}$, presumably due to extended crosslinking upon thermal exposition.

\section{Summary and Conclusions}

1) Three-functional oligoetherols with carbazole ring can be obtained starting from carbazole, by consecutive conversions with epichlorohydrin to 9-(2,3-epoxypropyl)carbazole, ring opening with diethanolamine, and finally by reaction with oxiranes $\mathrm{EO}$ or $\mathrm{PO}$.

2) The oligoetherols have similar properties as those used regularly for obtaining polyurethane foams except higher thermal resistance of the former.

3) Obtained oligoetherols are useful substrates for synthesis of polyurethane foams which have enhanced thermal resistance and remain unchanged upon long exposure at $150^{\circ} \mathrm{C}$. 


\section{REFERENCES}

[1] H. Fukuya, K. Miura and T. Murayama, "Photosensitive Polyether Derivatives,” Jpn Pat. 7409638, 1974.

[2] X. J. Ke, X. Z. Yan, N. Srisanit, M. Wang, J. W. Yang, X., F. Huang and S. Z. Zhong, "Holographic Storage in Carbazole-Azo Binary Compound Doped Polymer," Optics Communications, Vol. 217, No. 1-6, 2003, pp. 69-74.

[3] J. A Gratt and R. E. Cohen, “Optical Properties of Block Copolymers Containing Pendant Carbazole Groups and in situ Synthesized CdS Nanoclusters,” Journal of Applied Polymer Science, Vol. 88, No 1, 2003, pp.177-182. doi:10.1002/app.11620

[4] W. H. Zhu, R. Rao and H. Tian, "A Novel Family of Twisted Molecular Luminescent Materials Containing Carbazole Unit for Single-Layer Organic Electroluminescent Devices," Journal of Photochemistry and Photobiology A: Chemistry, Vol. 154, No 2-3, 2003, pp.169-177. doi:10.1016/S1010-6030(02)00325-8

[5] J. H. Lee, H. S. Woo, T. W. Kim and J. W. Park, "Blue Organic Light-Emitting Diodes with Carbazole-Based Small Molecules,” Optical Materials, Vol. 21, No. 1-3, 2003, pp. 225-229. doi:10.1016/S0925-3467(02)00141-6

[6] X. J. Zhang, Y. P. Thian and S. L. M. Jiang, "Zn(II) and Cd(II) N-Carbazolylacetates with Strong Fluorescence,” Polyhedron, Vol. 22, No 3, 2003, pp. 397-402. doi:10.1016/S0277-5387(02)01360-8

[7] S. Tirapattur, M. Belletete, N. Drolet, N. Leclerc and G. Durocher, "Steady-State and Time-Resolved Studies of 2,7- Carbazole-Based Conjugated Polymers in Solution and as Thin Films: Determination of Their Solid State Fluorescence Quantum Efficiencies,” Chemical Physics Letters, Vol. 370, No. 5-6, 2003, pp. 799-804.

\section{doi:10.1016/S0009-2614(03)00178-7}

[8] R. Lubczak, "Diols with Carbazole Ring and Their Aza Derivatives,” Heterocyclic Communications, Vol. 12, No. 3-4, 2006, pp. 201-208. doi:10.1515/HC.2006.12.3-4.201

[9] R. Lubczak, "Oligoetherols and Polyurethanes with Carbazole Ring in Side Chain,” Polimery, Vol. 53, No. 7-8, 2008, pp. 587-590.

[10] R. Lubczak, "Bifunctional Oligoetherols with Carbazole Ring,” Journal of Applied Polymer Science, Vol. 110, No 6 , 2008, pp. 3501-3507. doi:10.1002/app.28935

[11] R. Lubczak, "Linear Oligoetherols and Polyurethanes with Carbazole Ring,” Journal of Applied Polymer Science, Vol. 117, No. 1, 2010, pp.16-23.

[12] Z. Brojer, Z. Hertz and P. Penczek, "Epoxy Resins," WNT, Warsaw, 1972, pp. 462-463.

[13] Cellular Plastics and Rubbers, "Determination of Apparent (Bulk) Density, Polish (European) Standards PN-EN ISO 845-2000," Polish Committee for Standardization, 2000.

[14] Cellular Plastics, rigid, "Determination of Water Absorption, Polish (European) Standards PN-EN ISO 28961986,” Polish Committee for Standardization, 1987.

[15] Cellular Plastics, rigid, "Test of Dimensional Stability, Polish (European) Standards PN-EN ISO 2796-1986," Polish Committee for Standardization, 1986.

[16] Cellular Plastics, "Compression Test for Rigid Materials, Polish (European) Standards PN-EN ISO 844-1978," Polish Committee for Standardization, 1978.

[17] Z. Wirpsza, “Polyurethane,” WNT, Warsaw, 1991, pp. 48-57. 